\title{
Dawid Ślusarczyk
}

Ewangelikalna Wyższa Szkota Teologiczna, Wroctaw

\section{Muzyka w luterańskim zborze w pierwszych wiekach reformacji}

Problematyka dotycząca funkcji muzyki w obrządku luterańskim mimo licznych monografii, głównie niemieckojęzycznych, w dalszym ciągu pozostaje w obszarze zainteresowań hymnologów, historyków liturgii, teologów oraz muzyków kościelnych. Wiele publikacji wskazuje na priorytetowe znaczenie sztuki dźwięków już od początku reformacji. Autorzy podkreślają funkcję wspólnego śpiewu wiernych, wykształcenie nowego repertuaru pieśni oraz aspekt pedagogiczny i duszpasterski muzyki. Ów stan wiedzy stale uzupełniają badania, które systematycznie prowadzone są nad kulturą muzyczną Kościoła ${ }^{1}$. Obecnie wiadomo, że uczestnictwo wiernych w zreformowanej przez Lutra liturgii nie było tak duże, jak wcześniej sądzono. Wzorzec mszy łacińskiej oraz mentalność ówczesnego społeczeństwa były tak silne, że wspólnotowy śpiew wiernych upowszechniał się przez trzy kolejne stulecia. Także akompaniament organowy nie był zjawiskiem powszechnym - kosztowny instrument znajdował się w niewielkiej liczbie kościołów. Oprócz chorałów na nabożeństwach wykonywano muzykę artystyczną, której funkcja w nabożeństwie także ewoluowała, osiągając kulminację rozwoju w siedemnastym stuleciu.

Problematyka kultury muzycznej reformacji wynika z ówczesnej myśli teologicznej, która stworzyła zasady funkcjonowania sztuki dźwięków w ramach liturgii. Istotnym zagadnieniem jest także aspekt praktyczny - oprawa muzyczna kultu oraz konkretne gatunki uprawiane przez kompozytorów tworzących na potrzeby nowo powstałych parafii.

1 Interesujące wyniki badań znajdują się m.in. w: G. Stiller, Johann Sebastian Bach und das Leipziger gottesdienstliche Leben seiner Zeit, Kassel 1970; G. Strauss, Luter's Mouse of Learning: Indoctrination of the Young In the German Reformation, Baltimore London 1978; C. Schalk, Key Words In Chuch Music, St. Louis 1978; J. Herl, Luter's German Mass: A Congregational Hymn Sing?, [w:] „Doctrie and Practice” 1997, nr 1; R. Oettinger, Music as Propaganda in the German Reformation, Ashgate 2001. 


\section{Znaczenie muzyki w teologii luterańskiej}

Funkcja muzyki w obrządku luterańskim wytyczona została przez twórcę reformacji M. Lutra, jednak ostateczny kształt oprawy dźwiękowej nabożeństwa krystalizował się na przestrzeni wieków. Z grupy historycznych Kościołów protestanckich jedynie luterański rozwinął myśl o sztuce dźwięków, tworząc w rezultacie zwarty system, określany jako „teologia muzyki”2 („Theologie der Musik”). Źródła owej dyscypliny tkwią w spuściźnie pisarskiej Lutra, ale także w interpretacjach sukcesorów jego teologicznego dorobku. W formowaniu zasad istotne miejsce zajmowała także historia biblijna i opisane w niej zwyczaje dotyczące praktyki muzycznej.

Opinie i refleksje dotyczące „Pani Muzyki” znajdują się w wielu pracach reformatora, który mimo deklarowanego uwielbienia muzyce nie poświęcił osobnego traktatu. Waloryzacja tej dziedziny sztuki wyartykułowana została w korespondencji z kompozytorem Ludwigiem Senflem. W 1538 roku Luter napisał: „kocham muzykę, ponieważ jest bożym darem, powoduje radość serca, może pokonać złe moce, rozbrzmiewa w czasie pokoju, zaś w hierarchii sztuk mowa dźwięków zajmuje miejsce zaraz po teologii”'3. W tym samym roku ukazał się poemat Frau Musica, w którym reformator wyraził swój podziw i szacunek dla sztuki dźwięków. Bogaty repertuar tekstów oraz melodii chorałowych stworzonych przez Lutra wyraźnie świadczy o mocy tego środka przekazu w głoszeniu Ewangelii. Jednak obok pozytywnych wypowiedzi znaleźć możemy także fragmenty, w których funkcja muzyki sprowadzona została do sfery bytów neutralnych pod względem moralnym. Adriaforalność muzyki wynika z jej wartości estetycznych i siły oddziaływania, które mogą stać się wartością nadrzędną, tym samym przysłonić Słowo Boże. Aby trafnie oddać złożony problem luterańskiej koncepcji muzyki, omówimy jej funkcje duszpasterskie - liturgiczną oraz dydaktyczną (teologiczna). Owa typologia, zaproponowana przez Oskara Söhngena ${ }^{4}$, tworzy spójny obraz tego złożonego zagadnienia. W centrum luterańskiego nabożeństwa jest Słowo Boże, zaś wszystkie inne elementy, będące jedynie oprawą, schodzą na plan dalszy. Sztuka muzyczna powinna pomóc wierzącym w pogłębieniu wiary, ale nie jest niezbędna w celebracji liturgicznej. Wartość muzyki - zdaniem Lutra - tkwi zwłaszcza w zakresie nauczania, bowiem oprawa muzyczna słowa wzmacnia przesłanie Ewangelii: „sic praedicavit Deus evangelium etiam per musicam" . Jedność słowa i muzyki jest naturalną formą głoszenia prawd wiary

2 Termin szeroko omówiony został m.in. w pracy O. Söhngena Theologie der Musik (Kassel 1967).

3 R. A. Leaver, Music and Theology, Michigan 2007, s. 86.

4 O. Söhngen, Theologie..., dz. cyt., s. 108.

5 O. Brodde, Liturgie, [w:] Evangelisches Kirchenlexikon, Göttingen 1958, s. 1132. 
(„viva vox ewangelii”“), bowiem wiara rodzi się z tego, co się słyszy ${ }^{7}$. Dla Lutra muzyka jest darem bożym danym ludzkości, który przenika całe uniwersum, jednocześnie je porządkując. Reformator doceniał także muzykę instrumentalną, w której objawia się chwała Stwórcy - przy akompaniamencie instrumentów czcili Boga Prorocy, a zwłaszcza autorzy starotestamentowych psalmów ${ }^{8}$. Zauważyć należy, że tak wysoki status przyznany sztuce dźwięków był precedensem w całej historii chrześcijaństwa.

Drugi etap rozwoju luterańskiej teologii muzyki przypadł po śmierci M. Lutra (1546), a kształtowały go liczne konfrontacje i polemiki z przedstawicielami orientacji kalwińskiej. Przedmiotem owych dysput było ponowne rozpatrzenie kwestii oprawy muzycznej nabożeństwa oraz sformułowanie przepisów liturgicznych dla parafii obu konfesji. W rezultacie strona kalwińska obstawała przy ograniczeniu muzyki do śpiewu wiernych bez akompaniamentu, luteranie zaś uczynili z niej integralny element obrządku. Polaryzacja stanowisk wpłynęła pozytywnie na życie muzyczne w zborach wiernych ortodoksyjnej nauce Lutra. Od tego czasu angażowanie wysokiej klasy muzyków było priorytetowym zadaniem władz kościelnych, inne osiągnięcia to rozwój budownictwa organowego oraz upowszechnianie zasad muzyki wśród szerokich warstw społeczeństwa.

Pozycja muzyki w luterańskich parafiach wzmocniona została także dzięki XVII-wiecznej literaturze dewocyjnej. Autorzy dzieł adresowanych do wiernych życie w zaświatach przedstawiali jako stan harmonii z Bogiem, czego egzemplifikacją był śpiew zbawionych z chórami aniołów. Doczesne muzykowanie wiernych postrzegano jako „przedsmak życia wiecznego", namiastkę boskiej chwały. Efektem takiego ujęcia była kontemplacja utworów w świątyni oraz praktyczna nauka muzycznej profesji przez wspólnotę wiernych. W drugiej połowie XVI stulecia oprawa muzyczna nabożeństw przybierała bogatą i różnorodną formę, w ten sposób podnosząc muzykę, częściowo wbrew zaleceniom Lutra, do rangi centralnego elementu nabożeństwa. Wykonywany w kościele repertuar obejmował muzykę z tekstem religijnym (muzyka figuralna), często bez akompaniamentu, której wzorce wytyczyli kompozytorzy przełomu XVI i XVII wieku: Michael Praetorius, Sethus Calvisius czy Johannes Eccard. Dzieła instrumentalne, wykazujące wpływy muzyki tanecznej oraz stylu włoskiego, budziły początkowo sprzeciw władz kościelnych. Zmiana tego stanowiska nastąpiła po roku 1650, kiedy dostrzeżono bogactwo środków i sugestywność przekazu stylu koncertującego. W ten sposób przygotowany został grunt pod twórczość barokowych twórców - Dietricha Buxtehudego, Georga Philippa Telemanna oraz Johanna Sebastiana Bacha.

6 L. J. Irwin, Neither Voice nor Heart Alone. German Lutheran Theology of Music in the Age of the Baroque, New York 1993, s. 4

7 Por. św. Paweł, List do Rzymian 10, 17.

8 R. A. Leaver, Music..., dz. cyt., s. 90-92. 


\section{Muzyczna oprawa nabożeństwa}

Ryt nabożeństwa ustalony został przez Lutra w pierwszych latach reformacji. Dokładny opis kolejnych czynności liturgicznych zawarł reformator w dwóch traktatach: Formula Missae et Communionis pro ecclesia Vittembergensi (1523) oraz Deutsche Messe und Ordnung Gottesdiensts (1526). Struktura nabożeństwa wzorowana jest na Ordo missae, celem zaś jest uwielbienie Boga oraz zbliżenie form kultu do zaleceń zawartych w Ewangeliach'. W obu wersjach mszy Luter pozostawił niemal wszystkie części ordinarium oraz większość proprium missae (por. tab. 1). Bliżej rzymskiego wzorca sytuuje się Formula Missae, w której kolejność części liturgicznych jest niemal identyczna (z wyjątkiem ofiarowania ${ }^{10}$ oraz mszalnego kanonu). Znaczna modyfikacja nastąpiła trzy lata później w Deutsche Messe. Oprócz części stałych, z których dwie ostatnie pojawiają się opcjonalnie, Luter wykorzystał niemieckie tłumaczenia introitu oraz Pater noster, recytowane przez cały zbór. Ponadto język narodowy używany był także w pieśniach i psalmach, Wyznaniu wiary (Credo) oraz kazaniach, będących najistotniejszym elementem nabożeństwa. Perykopy Ewangelii, Credo oraz prefację nadal odczytywano podczas największych świąt kościelnych po łacinie.

\begin{tabular}{|l|l|l|}
\hline \multicolumn{1}{|c|}{ Msza Rzymska } & \multicolumn{1}{|c|}{ Formula Missae (1523) } & \multicolumn{1}{c|}{ Deutsche Messe (1526) } \\
\hline Introit & Introit & Psalm lub hymn \\
\hline Kyrie eleison & Kyrie eleison & Kyrie eleison \\
\hline Gloria & Gloria & \\
\hline Kolekta & Kolekta & Kolekta \\
\hline Epistoła & Epistoła & Epistoła \\
\hline Graduał (lub Sekwencja) & Graduał (lub Sekwencja) & Pieśń \\
\hline Alleluja & Alleluja & \\
\hline Ewangelia & Ewangelia & Ewangelia \\
\hline Credo & Credo & Credo \\
\hline Kazanie & Kazanie & \\
\hline
\end{tabular}

9 Por. F. C. Senn, Liturgy, [w:] The Oxford Encyklopedia of the Reformations, Oxford 1996, t. 2, s. 439.

${ }^{10} \mathrm{~W}$ interpretacji Lutra śmierć Chrystusa na wzgórzu Golgoty była jednorazowym aktem w dziejach zbawienia. W tym sensie nabożeństwo jest pamiątką, a nie - jak definiuje teologia katolicka - „aktualizacją wydarzenia, które dokonało się po to, by wiecznie trwać”. B. Migut, Ofiara Chrystusa w ujęciu teologii liturgicznej, [w:] „Liturgia Sacra”, 24 (2004) nr 2, s. 232. 


\begin{tabular}{|c|c|c|}
\hline \multicolumn{3}{|l|}{ Ofertorium } \\
\hline Sekreta & & Niemiecka parafraza Ojcze nasz \\
\hline Prefacja & Prefacja & \\
\hline Sanctus, Benedictus & Sanctus, Banedictus & \\
\hline Podniesienie & Konsekracja & $\begin{array}{l}\text { Konsekracja i dystrybucja Komu- } \\
\text { nii (w trakcie Sanctus i Agnus Dei } \\
\text { ad libitum) }\end{array}$ \\
\hline Pater noster & Pater noster & \\
\hline Agnus Dei & Agnus Dei & \\
\hline Antyfona & Antyfona & \\
\hline Modlitwa dziękczynna & Modlitwa dziękczynna & Modlitwa dziękczynna \\
\hline Błogosławieństwo & Błogosławieństwo & Błogosławieństwo \\
\hline
\end{tabular}

Tabela 1. Porównanie mszy rzymskiej ze zreformowanym porządkiem M. Lutra"1.

W większości parafii oprawę muzyczną nabożeństwa tworzył zespół wokalny (chór złożony z wykwalifikowanych śpiewaków lub uczniów przykościelnej szkoły), duchowni oraz wierni.

Nabożeństwo rozpoczynał chór, który intonował hymn lub psalm (zalecanym przez Lutra introitem był Psalm XXXIV). Ponadto zespół wokalny wykonywał części stałe liturgii oraz pieśń po czytaniu - graduał - Nun bitten wir den Heiligen Geist (por. tab. 2). Sanctus oraz Agnus Dei lub literackie parafrazy tych części śpiewano w trakcie dystrybucji Wieczerzy Pańskiej.

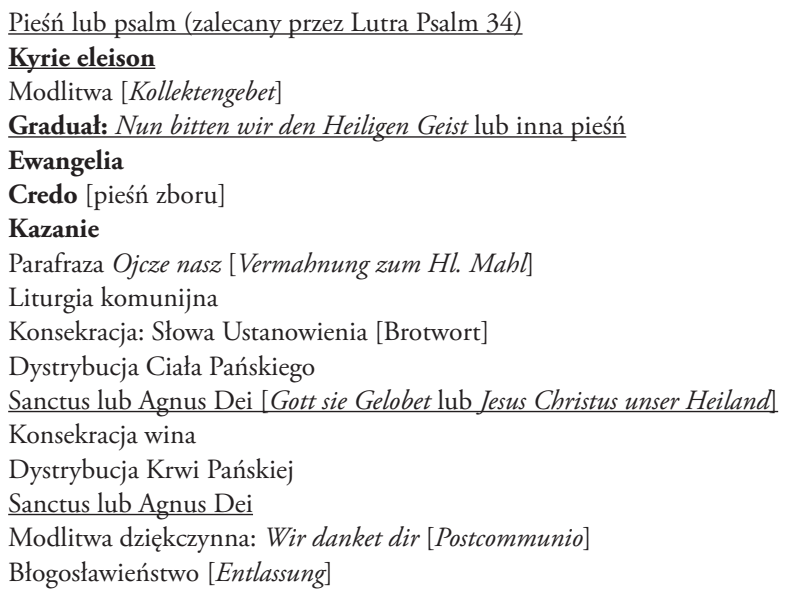

Tabela 2. Porządek nabożeństwa według Deutsche Messe ${ }^{12}$.

${ }^{11}$ Pogrubionym drukiem wyróżniono części wspólne dla wszystkich porządków.

${ }^{12}$ Podkreślono części nabożeństwa opracowywane muzycznie. 
Opracowania partii chóralnych były najczęściej jednogłosowe, ze względu na stopień komplikacji utwory polifoniczne wykonywano zdecydowanie rzadziej. Powodem był brak wykwalifikowanych śpiewaków, którzy mogli wykonać repertuar tego typu. Profesjonalne zespoły wokalne działały głównie w dużych parafiach ${ }^{13}$, natomiast $\mathrm{w}$ mniejszych zborach chór zasilali przeważnie adepci - uczniowie lub studenci. Oprócz kompozycji solowych wokaliści wspomagali śpiew zboru w trakcie pieśni. Istotnym zadaniem chóru było nauczanie nowych chorałów, których korpus stworzony na początku reformacji stale poszerzano.

Teksty modlitw, czytania ewangeliczne oraz prefację wykonywał celebrujący liturgię duchowny. Nieskomplikowane aklamacje wykorzystywały formuły melodyczne oparte na materiale średniowiecznych tonów psalmowych. Ten typ śpiewu liturgia luterańska przejęła z repertuaru gregoriańskiego.

Cały zbór brał udział w muzycznej oprawie liturgii sporadycznie. Wierni wykonywali jedną lub dwie pieśni w trakcie nabożeństwa: niemiecką parafrazę Credo (Wir Gläuben all an einen Gott) oraz chorał Gott sei Gelobet, śpiewany w trakcie komunii. Z czasem wierni śpiewali częściej - wykształcił się bowiem nowy repertuar pieśni, które stopniowo włączano do nabożeństw. Melodie chorałowe komponowane były na materiale modalnym i charakteryzowały się nieskomplikowaną linią melodyczną (melodyka typu sylabicznego, pozbawiona rozbudowanych melizmatów), a ich budowa wewnętrzna składała się z kilku ogniw ${ }^{14}$. Wiele przykładów pieśni to kontrafaktury utworów religijnych oraz świeckich, a także adaptacje chorału gregoriańskiego do nowego tekstu.

Luter wytyczył nowy kierunek rozwoju obrządku oraz refleksji teologicznej nad sensem i znaczeniem czynności liturgicznych. Nie był to ostateczny wzorzec, bowiem każde miasto i region Niemiec tworzyły własny ryt kościelnego obrządku - zmodyfikowaną mszę Lutra, który wydawano następnie w formie tzw. agendy. J. Herl podaje liczbę kilkuset ksiąg tego typu wydanych w latach 1523$1780^{15}$. Warianty lokalne nie były dalekie od pierwowzoru Deutsche Messe, jako przykład podajemy porządek nabożeństwa porannego (Haupt-Predight) z Lubeki (tab. 3). Na podstawie rytu lubeckiego, powstałego sto lat po reformie Lutra, stwierdzić można, że udział wiernych w liturgii zasadniczo nie uległ zmianie.

${ }^{13} \mathrm{~J}$. Herl, Worship Wars in Early Lutheranism. Choir, Congregartion, and tree centuries of conflict, Oxford 2004, s. 14.

${ }^{14}$ Szerzej na ten temat w: D. Ślusarczyk, Poczattki pieśni protestanckiej na przyktadzie twórczości choratowej M. Lutra, „Analecta Cracoviensia”, 38-39 (2006-2007), s. 557-567.

15 J. Herl, Worship Wars in Early Lutheranism. Choir, Congregartion, and tree centuries of confict, Oxford 2004, s. 206-207. Por. także: E. Sehlinh, Die evangelischen Kirchenordungen des XVI. Jahrhunderts, Leipzig 1902. 


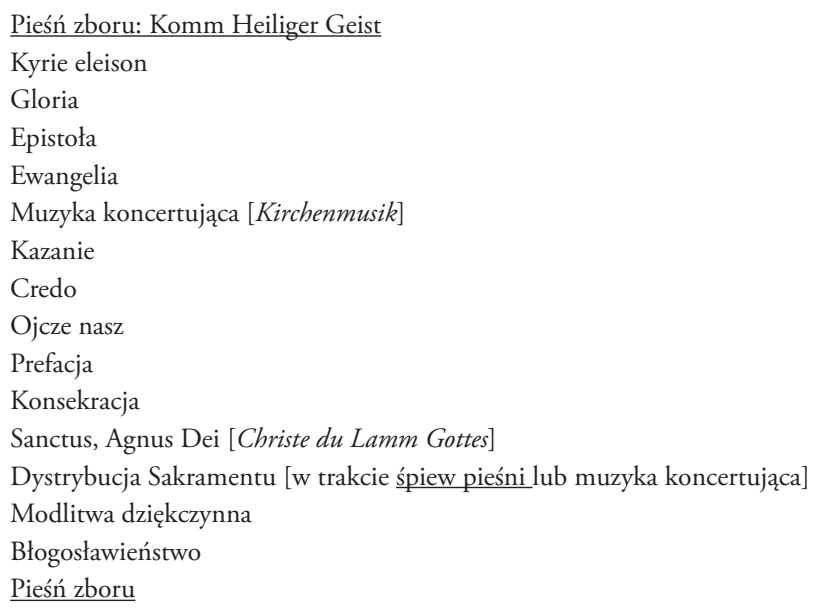

Tabela 3. Porządek nabożeństwa porannego (Haupt-Predight) w Lubece ${ }^{16}$. Lubeka, II połowa XVII wieku.

\section{Muzyka instrumentalna w liturgii}

Najczęściej wykorzystywanym instrumentem w luterańskiej liturgii były organy, chociaż w Niemczech na początku reformacji liczba tych instrumentów nie była duża. Ze względu na koszt budowy jedynie zamożne kościoły miejskie oraz reprezentacyjne kaplice pałacowe wyposażone były w organy. W XVI w. funkcja tego instrumentu polegała na wspieraniu (dublowaniu) głosów chóru oraz podawaniu tonacji śpiewakom (tzw. preludiowanie). Akompaniament organowy często realizowany był według średniowiecznej praktyki alternatim, polegającej na naprzemiennym wykonywaniu strof hymnu przez chór oraz organy. Utworami solowymi były intabulacje - transkrypcje wokalnych utworów zapisane w systemie tabulatorowym oraz tzw. preambula lub preludia, które improwizowano przed kompozycją wokalną. Celem owych krótkich interpolacji było podanie właściwej tonacji śpiewakom, a także instrumentalistom ${ }^{17}$. Znaczenie organów w liturgii wzrasta w połowie XVII w. Nowy styl importowany z południa Europy wymagał od muzyków coraz większych umiejętności technicznych i improwizatorskich. Oprócz akompaniamentu organista zobowiązany był realizować bas figurowany (basso seguente, basso continuo). Wzrosła także liczba kościołów wyposażonych w instrumenty oraz udział organów w celebracji liturgicznej. Wymaga-

${ }^{16} \mathrm{Na}$ podstawie: J. Bugenhagen, Lübecker Kirchenordnung Braunschweig, Lübeck 1531. W tekście wyróżniono pieśni z udziałem zgromadzonych w świątyni wiernych.

${ }^{17}$ Por. E. Higginbottom, Organ music and the liturgy, [w:] The Cambridge Companion to the Organ, Cambridge 1990, s. 130-135. 
nia rady parafialnej zatrudniającej nowego organistę były wysokie oraz wszechstronne, o czym świadczy przykład Johanna Heinricha Buttstedta (1666-1727) aplikującego na posadę erfurckiego Predigerkirche w 1693 roku $^{18}$. Kandydat na muzyka kościelnego zobowiązany był m.in.:

1. grać w trakcie nabożeństw porannych i popołudniowych (nieszpory) w niedziele i święta; wykonywać Kirchenmusik ${ }^{19}$ po kazaniu; pozostawać w kościele do końca nabożeństwa i akompaniować do pieśni zboru; improwizować preludia na tematy chorałowe (przygrywki), a także organowe interpolacje (mitspielen) między zwrotkami; akompaniować uczniom na regale w trakcie egzaminów szkolnych;

2. wykonywać półgodzinne recitale podczas popołudniowego nabożeństwa w dniu św. Jana (24 czerwca);

3. stroić organy oraz usuwać usterki techniczne instrumentu;

4. prowadzić pobożne życie według zasad chrześcijańskich.

W latach 1650-1750 akompaniament organowy do pieśni stawał się coraz powszechniejszy, zwłaszcza w parafiach miejskich, jednak w dalszym ciągu nie był on regułą. Ponadto instrument milczał w czasie nabożeństw żałobnych (pogrzebów) oraz w okresie postu. Priorytetowym zadaniem organów było utrzymanie właściwej tonacji śpiewających, a także tempa wykonywanej pieśni. Organista akompaniował z przygotowanej wcześniej harmonizacji lub improwizował. Czynności te nie były trudne z uwagi na skromny jeszcze wówczas repertuar pieśni.

Na przełomie XVII i XVIII w. upowszechniła się w Niemczech praktyka grania basu cyfrowanego, o czym świadczy duża liczba wydanych druków z takim zapisem partii organowej. Bas realizowano w utworach wokalno-instrumentalnych (Kirchenmusik), a także w kompozycjach z obsadą kameralną. Osobną grupę tworzyły dzieła przeznaczone wyłącznie na organy. Najczęściej były to wstępy do pieśni lub improwizacje między jej zwrotkami (mitspielen). Każda z tych form improwizowana była przez organistę, zaś samą umiejętność klasyfikowano wysoko w hierarchii cech warsztatu wirtuoza. Preludia chorałowe posiadały różne formy i architektonikę wewnętrzną. Zgodnie z klasyfikacją Daniela Türka (II połowa XVIII w.), można wyróżnić cztery ukształtowania formalne: [1] preludia $\mathrm{z}$ kolorowanym cantus firmus (z imitacją strof chorału w akompaniamencie), [2] fuga, [3] forma triowa oraz [4] fantazja chorałowa ${ }^{20}$.

Inną kategorię tworzą preludia do Kirchenmusik oraz utwory pełniące funkcje wstępu i zakończenia nabożeństwa. Celem pierwszej grupy było ujednolicenie stroju wszystkich instrumentów wykonujących dane dzieło. Organista improwizował

18 Za: J. Herl, Worship Wars..., dz. cyt., s. 131.

${ }^{19}$ Najprawdopodobniej kandydat powinien wykonywać partię basso continuo w kompozycjach wokalno-instrumentalnych.

${ }^{20}$ Za: J. Herl, Worship Wars..., dz. cyt., s. 144. 
zatem tak długo i w takich tonacjach, aby umożliwić wszystkim instrumentalistom korektę stroju. Wykonywanie tego rodzaju improwizacji było szczególnie trudne z uwagi na nieprzewidywalny czas trwania utworu. Muzyka organowa brzmiała także w skrajnych częściach nabożeństwa, a początki tego zwyczaju sięgają końca XVII stulecia. Na początku XVIII w. na zakończenie celebracji liturgicznej zaczęto wykonywać postludia. Kompozycje te miały różną formę i składały się często z kilku odcinków zestawionych na zasadzie kontrastu. Obok ogniw o wirtuozowskim charakterze występowały fragmenty przeprowadzone w imitacji ścisłej. Dobrym przykładem są dzieła Franza Tundera oraz Dietricha Buxtehudego, na których wzorował się Johann Sebastian Bach. W odróżnieniu od preludiów do dzieł wokalno-instrumentalnych postludia można było wykonywać z zapisu tabulatorowego lub nutowego. Nie wykluczało to jednak możliwości improwizowania utworu lub modyfikowania jego architektoniki w zależności od konkretnej potrzeby.

Kultura muzyczna reformacji krystalizowała się przez wiele dziesięcioleci, przyjmując inny kształt w każdym z jej nurtów. Podczas gdy dla wyznawców reformatora z Gandawy istotny był jedynie wspólnotowy śpiew wiernych, luteranie przyznali sztuce dźwięków status wyjątkowy, nadając jej charakter modlitwy. Teologiczne podstawy muzyki dały ogromne możliwości twórcom i wykonawcom obrządku luterańskiego, a ich owocem jest szeroki repertuar dzieł, z których do dziś korzystają kolejne pokolenia muzyków kościelnych.

\section{Music in the Lutheran congregation in the first centuries of the Reformation}

The article discusses the musical culture of the Church from M. Luther's reform to mid-18th century. The author presents the premises of the Protestant theology, which made it possible for both music forms and performance practice to develop. The consequence of the theological thought was to award music an exceptionally high status in the hierarchy of the arts. The article also deals with the vocal and instrumental compositions which functioned within the reformed liturgy.

Słowa kluczowe reformacja, luteranizm, teologia muzyki, nabożeństwo luterańskie, muzyka organowa

Keywords the Reformation, Lutheranism, theology of music, Protestant divine service, organ music 
